\title{
Distribution of Agonostomus monticola and Brycon behreae in the Río Grande de Térraba, Costa Rica and relations with water flow
}

\author{
Thiago Cotta Ribeiro and Gerardo Umaña Villalobos
}

Fish monthly samples were made in three tributaries and in the main stream in order to study population dynamics and the influence of flow on abundance of Agonostomus monticola (Mugilidae) and Brycon behreae (Characidae) in the basin of Térraba River Basin (Costa Rica). Flow was seasonal in these rivers, with peak flow in October. Recruitment was different among the species, $B$. behreae recruited from January to June and A. monticola all year round with a peak in June-July and October-November. Juveniles were more abundant in smaller streams. Abundance was higher in general during low flow and low turbidity periods. The results suggest that the streams have an important role in the maintenance of both species in the ecosystem, where juveniles can use the streams as nursing habitats during their development, allowing these small streams to be considered as essential fish habitats. Also, it was determined that the increased volume and turbidity of water can significantly affect the proportion of adults and juveniles between the main river and its tributaries.

Com o objetivo de estudar a biologia de Agonostomus monticola (Mugilidae) e Brycon behreae (Characidae) da bacia do rio Térraba (Costa Rica), coletas mensais destas duas espécies foram feitas em diferentes pontos da bacia. A dinâmica populacional entre as categorias de tamanho dos peixes entre três tributários e rio Térraba foram analisados, bem como a variação da abundância dos peixes de acordo com as variações do nível das águas ao longo do ano. A flutuação do nível das águas é sazonal nestes rios, com um pico máximo em outubro. O recrutamento foi diferente entre as espécies, $B$. behreae apresentou o recrutamento de janeiro a junho e $A$. monticola durante todo o ano com um pico nos meses de junho-julho e outubronovembro. Juvenis foram mais abundantes nos riachos menores. A abundância foi, em geral, maior nos períodos de baixo nível de água e baixa turbidez. Os resultados sugerem que os córregos têm um papel importante na manutenção de ambas as espécies neste sistema, onde os indivíduos jovens podem usar os córregos como habitats de refúgio e proteção durante o seu desenvolvimento, o que faz estes pequenos tributários serem considerados como um habitat essencial para essas espécies. Verificamos também que o aumento do volume e da turbidez da água pode afetar significantemente a dinâmica da proporção de adultos e juvenis entre o rio principal e seus tributários.

Key words: Population dynamics, Fish recruitment, Environment conservation.

\section{Introduction}

Previous studies have demonstrated important correlations between the environment and the distribution of organisms (Guisan \& Zimmerman, 2000; Floeter et al., 2001; Baumar, 2002; Bexiga et al., 2002; Magalhães et al., 2002; Bergenius et al., 2005). Indeed, it is common the use of the term "essential habitat for fish" in management and conservation projects, referring to the environmental conditions required for an individual to be able to spawn, the offspring to hatch, eat and develop until its maturity (Wanat, 2002). Bexiga et al. (2002) showed the utilization of the estuarine region as breeding zones by some fish species, where salinity, nutrients and refuge are important factors for the movement and distribution of fish species. Also, Inoue \& Nunokawa (2002) found that variations of habitat along the river have significant effects in the distribution and abundance of species.
Large scale events such as dry or rainy seasons usually alter the ecological structure of communities through mortality and mass migrations (Magalhães, 1993), having also local effects over the habitat affecting abundance (Inoue \& Nunokawa, 2002) and the biotic interactions within fish communities (Godinho et al., 1997; Bexiga et al., 2002).

For instance, flow increases in the rainy season may flood the plains (Leopold et al., 1964). According to LoweMcConnell (1987) these dynamic environments offer a real mosaic of microhabitat for fish. Floods have also a great importance in the exchange of matter between the river and the adjacent plain (Colwell \& Futuyma, 1971).

The species Agonostomus monticola, also known as "tepemechín", is characterized as catadromous, i.e., individuals swim toward the sea or estuaries to reproduce (McDowall, 1998; Fievet et al., 2001). Agonostomus monticola lives in waters with current varying from moderate to high 
speeds and can resist the torrents of nearby waterfalls. They can be found in streams and rivers with a distribution from sea level to $650 \mathrm{~m}$ a.s.l., tolerating temperatures between 20 and $31^{\circ} \mathrm{C}$ (Bussing, 2002).

Some possible limiting factors for the distribution of the A. monticola are the currents, water flow and turbidity. Therefore, well oxygenated waters, non-altered basins and moderate to high water flow are factors that are important for the survival of $A$. monticola (Cruz, 1987). These fishes show a seasonal reproduction period. For example, the gonads of A. monticola that lives in rivers of the Atlantic slope of Honduras, Central America are fully developed in both sexes by the end of the rainy season (Cruz, 1987). This raises the possibility that its reproductive behaviour is related to the seasonality of rains, similar to other Mugilidae, like Mugil curema, which also have patterns of reproductive behaviour linked to local environmental events such as the dry and rainy seasons (Baumar et al., 2003).

Besides A. monticola, this work also studied the Brycon behreae, the "machaca", which is restricted to freshwater environments. This species lives in rivers and streams with current velocity from moderate to high. They live in schools over rocky or sandy bottoms and are omnivorous. The juvenile consume mainly insects, crustaceans and fishes and, as they grow, they increase the proportion of leaves, flowers, fruits and seeds in their diets (Bussing, 2002; Ribeiro \& Ureña, 2009). They can be found from 10 to $640 \mathrm{~m}$ a.s.l. and tolerate water temperature between 21 and $29^{\circ} \mathrm{C}$. They live in the Pacific slope between the rivers near Quepos in Costa Rica, down to River San Pedro in West Panama (Bussing, 2002).

Both species were chosen for the present study because of their importance in the region. These native species are very abundant and used as food by the local human population. Brycon behreae is an endemic species of Costa Rica with very little information about its life history.

The Térraba River is actually part of a hydroelectric project, where a dam will be built. Then, the understanding of ecology and behavior of these fishes is very important to preserve these two species in the region. The creation of a hydroelectric dam is an activity that cannot be executed before the survey of the environmental impacts with a multidiscipline approach. There is no doubt that this sort of intervention is one of the main anthropic activities able to affect environmental factors that determine the structure of hydric systems communities (Floeter et al., 2001; Magalhães et al., 2002; Robertson \& Winemiller, 2003). The construction and operation of such facilities can alter the flow of natural regime and compromise the fish communities, causing mortality and local extinctions (Duncan \& Lockwood, 2001).

The present study has as main objectives to: (i) determine distribution patterns of the organisms between the Térraba River and in some of its streams; (ii) establish the ecological importance of these streams for the development of both species in the Térraba basin by comparing the proportions of adults and juveniles between each stream and the main river; and (iii) determine the effect of flow increase during the rainy season on both populations. Additionally, we discuss the feasible effects of the dam project in this basin on both populations based on data obtained in another basin intercepted by a barrage.

\section{Material and Methods}

\section{Study area}

The study was conducted in the Térraba River and three tributaries: the streams Ojochal, Cañal Blancal and Brujo. This river is located in the South Pacific of Costa Rica and forms along with the rest of its affluents one of the biggest basins of the country. The collection places were distributed from the mouth of the river to regions near the cities of Palmar Norte and Buenos Aires, covering a distance of $70 \mathrm{~km}$ (between the two most distant points). The three streams were used as natural replicas for comparison of population structures between streams and the main river.

In this period a total of 8 points were sampled monthly from March 2004 to February 2005, two in Térraba River and two in each one of the three streams studied (Fig. 1). Ojochal, located near the mouth of the Térraba, known as Boca Coronado; Caña Blancal, located in Palmar Norte, approximately $30 \mathrm{~km}$ upstream of Ojochal; and Brujo, located $40 \mathrm{~km}$ upstream of Cañal Blancal and $70 \mathrm{~km}$ from Ojochal. The study area is a region with low altitudes in which the lowest collection point (Ojochal) is located at $1 \mathrm{~m}$ and the highest point (Brujo) at $190 \mathrm{~m}$ above sea level. Two collection points in the streams were located close to the confluence with the main river, and approximately $2.5 \mathrm{~km}$ upstream. Both collection points at the Térraba River are near Palmar Norte City are $3 \mathrm{~km}$ apart from each other. The downstream point was called Palmar Norte and the upstream point called Térraba.

\section{Data collection and samplings}

The flow was calculated through the width, depth and current speed. The width was measured using a tape measure; the average depth was obtained from three equidistant measures across the stream, using a graduated stick, and the average speed of the current with a digital water velocity meter from Global Flow Probe ${ }^{\circledR}$. The three variables were measured over a same transversal section of each stre am monthly. The average flow of the Térraba River was provided by the Instituto Costarricense de Electricidad (ICE), which maintains a permanent monitoring station in this river.

To calculate the turbidity, samples of water were collected and analysed with a LaMotte ${ }^{\circledR}$ nephelometer in laboratory.

The fish were collected using an electro fishing Samus ${ }^{\circledR}$ voltage regulator device. In Palmar Norte, apart from electro fishing, two hauls with nets $140 \mathrm{~m}$ long and 3.5 inches mesh were used. Most of the fish were returned to water after being measured, and only a few were sacrificed for gonadal verification.

In each collection with electro fishing, the duration and the endeavour area $\left(\mathrm{m}^{2}\right)$ were written down. We attempted to always run the same effort of fish capture. Fish were 


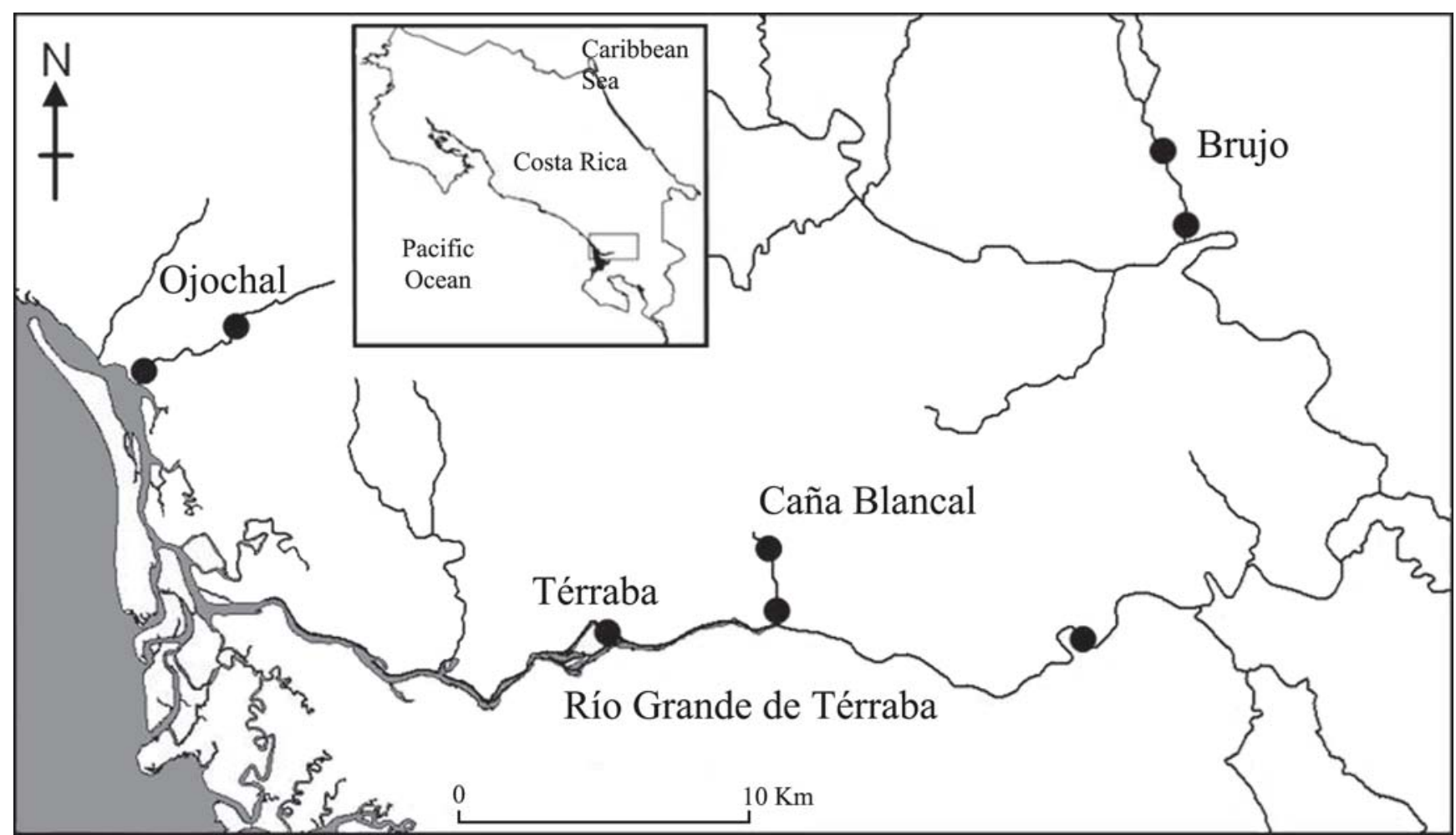

Fig. 1. Study area, the main River Térraba and Streams Ojochal, Caña Blancal and Brujo with the respective data recollection points.

separated in two categories (adults and juvenile) according to size, based on the minimum length of a mature specimen (with fully developed gonads). That way, individuals of $B$. behreae bigger than $15 \mathrm{~cm}$ were considered adults, as well as $A$. monticola bigger than $12 \mathrm{~cm}$ of total length (Lt). Individuals at the immediately post-larval stage measuring 2 to $3.9 \mathrm{~cm}(\mathrm{Lt})$ were considered recruits for being the smallest sizes captured in the system. Recruitment is the arrival of recruits in the local population. The intermediate sizes were considered juveniles.

Additionally, the presence of both species was checked in three points at Tepemechín River near the City of Pejibaye in Costa Rica, using electrofishing and diving. According to fishermen, local inhabitants and to published data by Bussing (2002), A. monticola inhabited the Tepemechin River before it be intercepted by a dam.

\section{Data analysis}

In order to verify possible differences in the number of juveniles and adults at each site, chi-square tests using a contingency table were performed for each site, for both species. The variation in number of individuals and their relation to the environmental variables changes (turbidity and rainfall) were also determined by a chi-square independence test. Similar approach has been applied before (Behr, 2008), where chi-square was used to investigate differences in catch abundance of some species between points. All tests were performed using the software Systat ${ }^{\circledR}$.

\section{Results}

A total of 1,301 A. monticola and 723 B. behreae were counted during the study. The flow presented an increase in all streams during the month of October, and the Térraba River reached a maximum of $1,180 \mathrm{~m}^{3} / \mathrm{s}$ at this month (Fig. 2).

Brycon behreae presented a clear and concentrated recruitment in the months of January, February, March, April, May and June (Fig. 3), a period of low flow (Fig. 2) and $A$. monticola, recruitment was observed all year long, with massive peaks in the months of June, July, October and November (Fig. 4) in Térraba River.

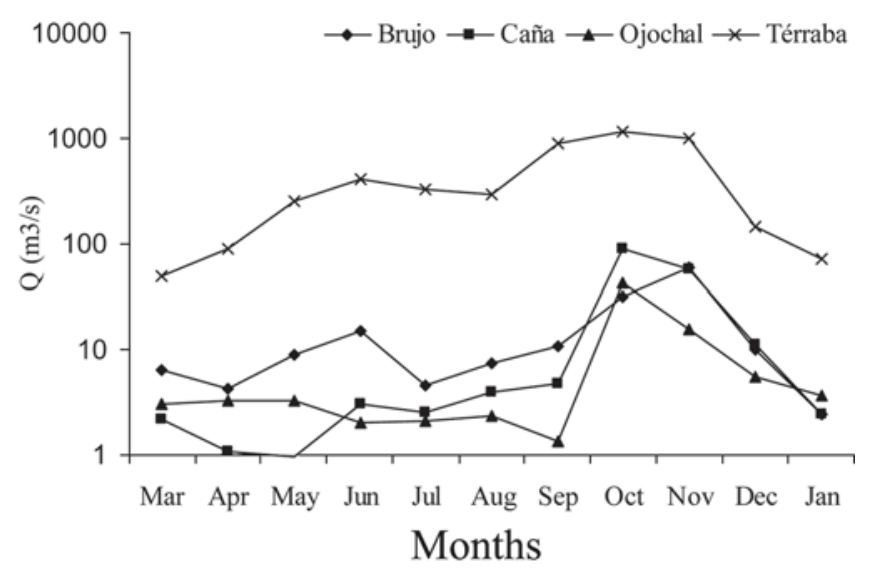

Fig. 2. Month flow variation of study sites. 


\section{Brujo}

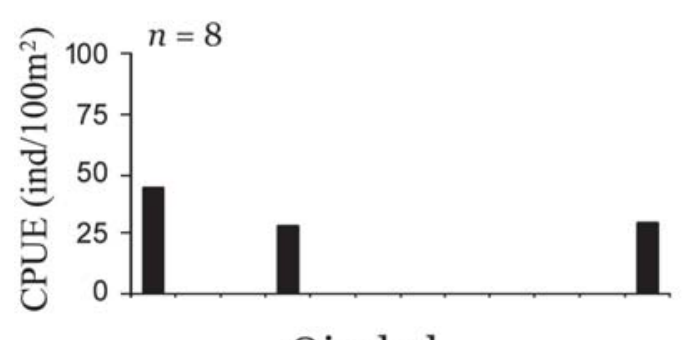

Ojochal

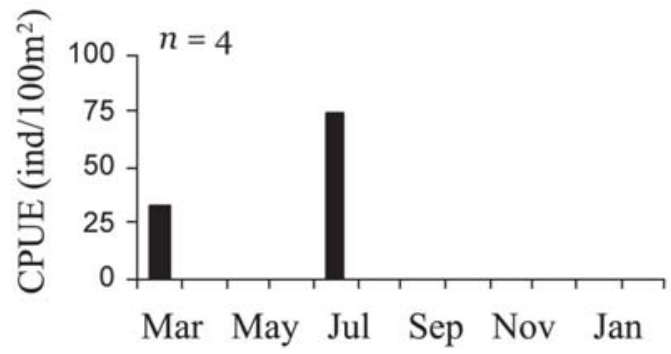

Caña Blancal

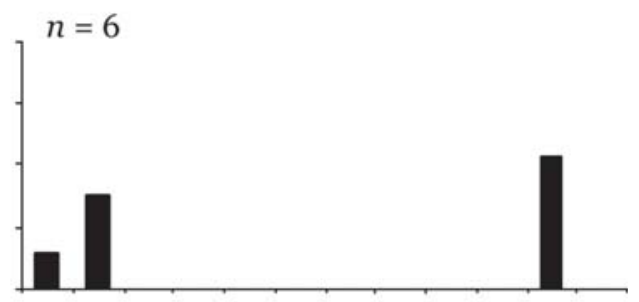

Térraba

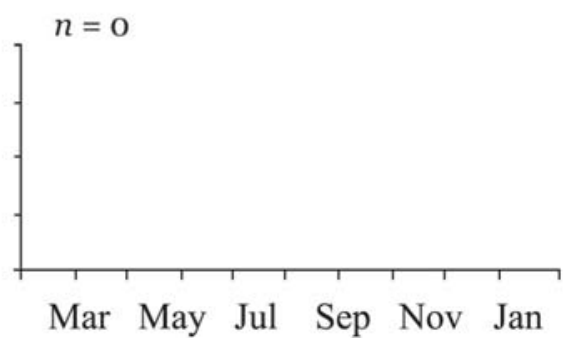

Fig. 3. Capture per unit effort (CPUE) by month for Brycon behreae recruits in the Térraba River and three tributaries.

It is possible that the recruits of $A$. monticola do not inhabit the main river, but use it as a crossing path to reach different streams where they develop. This is deduced from the following evidences: the catadromous condition of this species, the low number of juveniles in the Térraba River when compared with streams (Fig. 5), the existence of massive peaks of recruits of $A$. monticola using the main river as a path and also the absence of recruits of $B$. behreae (which are potamodromous) colonizing the Térraba River (Figs. 3 and 4).

According to the analysis there is a significant difference between adults and juveniles within each site, except by one. For A. monticola the analysis showed a
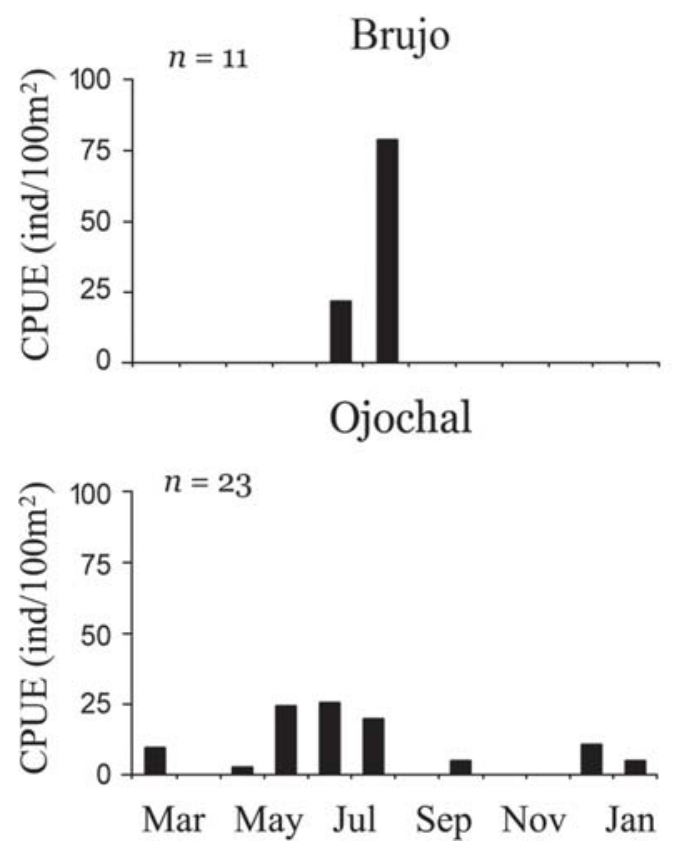

significant higher quantity of juveniles in the streams (Fig. 5) (Caña Blancal: $\chi^{2}=59.645 ; \mathrm{df}=1 ; \mathrm{p}<0.0001$; Brujo: $\chi^{2}=$ 111.905; $\mathrm{df}=1 ; \mathrm{p}<0.0001 ;$ Ojochal: $\chi^{2}=158.340 ; \mathrm{df}=1 ; \mathrm{p}<$ $0.0001)$ and in the main river (Térraba), either including $\left(\chi^{2}\right.$ $=166.745 ; \mathrm{df}=1 ; \mathrm{p}<0.001)$ or not including $\left(\chi^{2}=24.253 ; \mathrm{df}\right.$ $=1 ; \mathrm{p}<0.000)$ the recruits. Brycon behreae also presented a higher number of juveniles than adults in the streams (Caña Blancal: $\chi^{2}=226.039 ; \mathrm{df}=1 ; \mathrm{p}<0.000$; Brujo: $\chi^{2}=$ 107,692; df $=1 ; \mathrm{p}<0.000 ;$ Ojochal: $\chi^{2}=13.067 ; \mathrm{df}=1 ; \mathrm{p}<$ $0.000)$. The Térraba River was the only site with no significant difference between the number of juveniles and adults (Fig. 6).

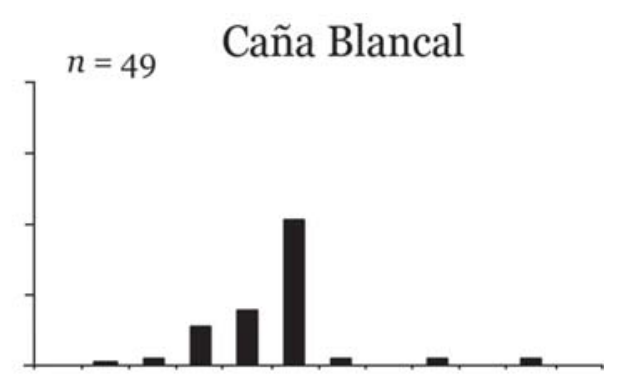

\section{Térraba}

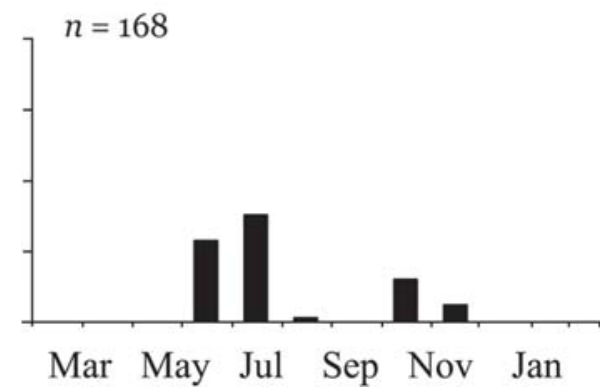

Fig. 4. Capture per unit effort (CPUE) by month for Agonostomus monticola recruits in the Térraba River and three tributaries. 


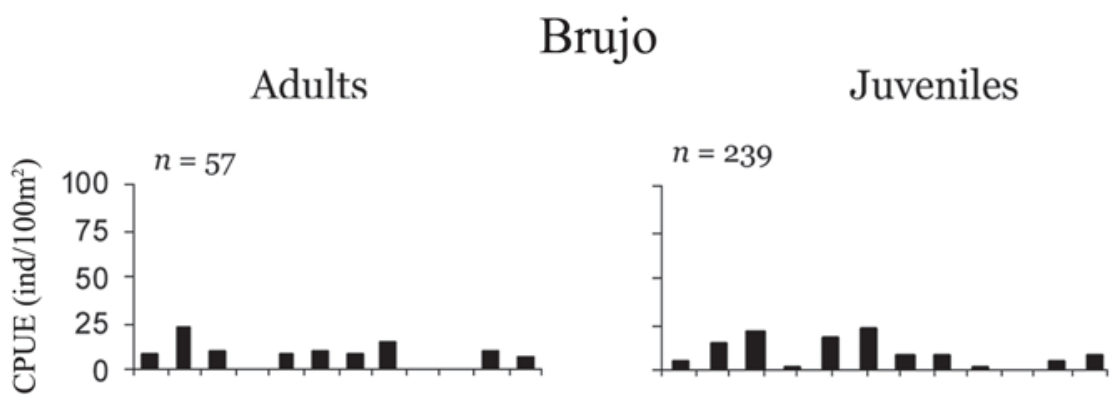

\section{Caña Blancal}
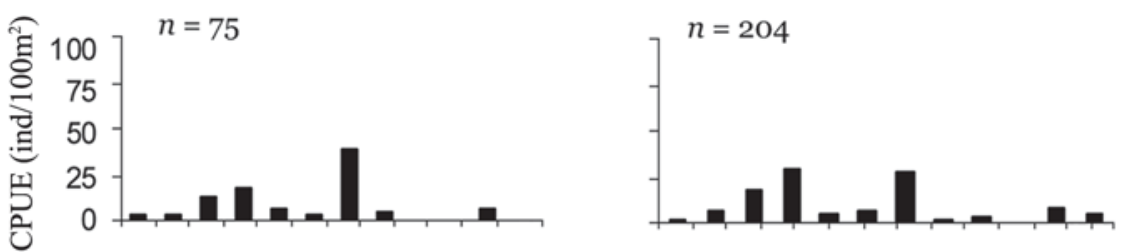

\section{Ojochal}
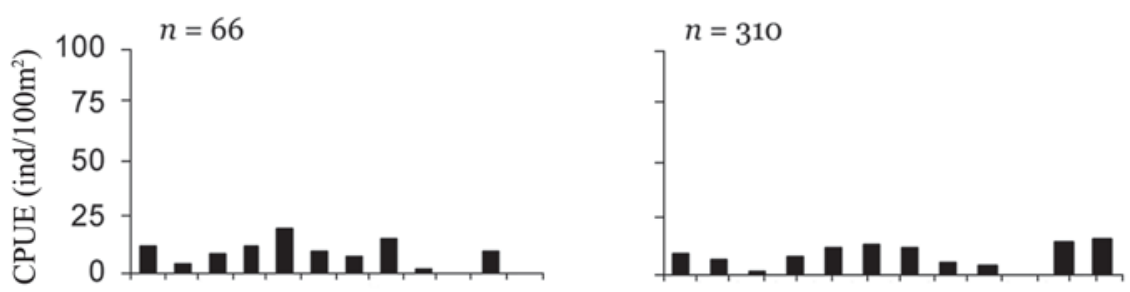

\section{Térraba}
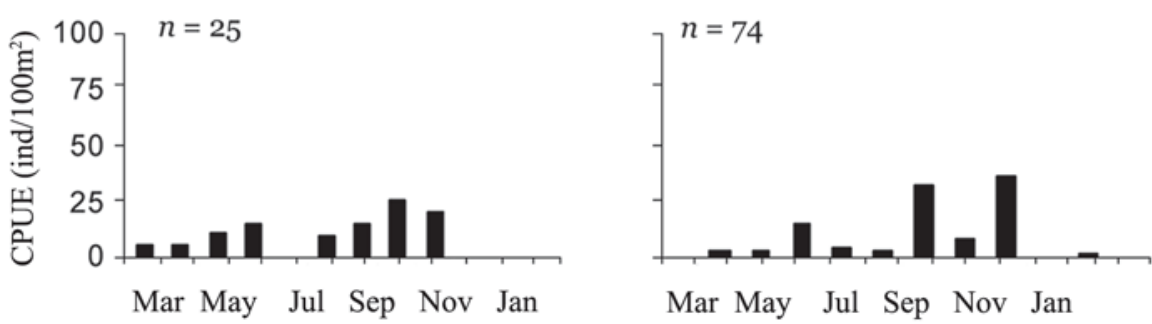

Fig. 5. Capture per unit effort (CPUE) by month for Agonostomus monticola juveniles and adults in the Térraba River and three tributaries.

A higher number of $B$. behreae was found during periods of low flow, with 629 individuals against the 94 found in the high flow season $\left(\chi^{2}=397.153 ; \mathrm{df}=1 ; \mathrm{p}<0.001\right)$. During the season of less turbidity (Fig. 7) 568 individuals were collected against 155 during the higher turbidity season $\left(\chi^{2}=238.713\right.$; $\mathrm{df}=1 ; \mathrm{p}<0.001)$. For $A$. monticola, the abundance was also higher during the season of low flow, with 750 individuals collected in this period, and 551 individuals collected in the high flow season $\left(\chi^{2}=47.656\right.$; df $\left.=1 ; p<0.001\right)$. When considering turbidity, more individuals were collected at low turbidity with 703 individuals against the 598 individuals collected at high turbidity levels $\left(\chi^{2}=8.474 ; \mathrm{df}=1 ; \mathrm{p}<0.004\right)$. Despite the general reduction of fish abundance during the periods of higher flow, there was an significant increase in the number of individuals of $A$. monticola in Térraba River (Fig. 5) when the places were analyzed separately $\left(\chi^{2}=26.791\right.$; $\mathrm{df}=1 ; \mathrm{p}<0.001)$.

Samplings in the three points upstream of the dam in Tepemechin River resulted in 10 specimens of the genus Brycon and many individuals of the families Gobiidae and Poecilidae. No individuals of $A$. monticola were neither collected nor observed.

\section{Discussion}

The present study suggests that the streams have an important ecological role in the development of juveniles of $B$. behreae and A. monticola, contributing with the 


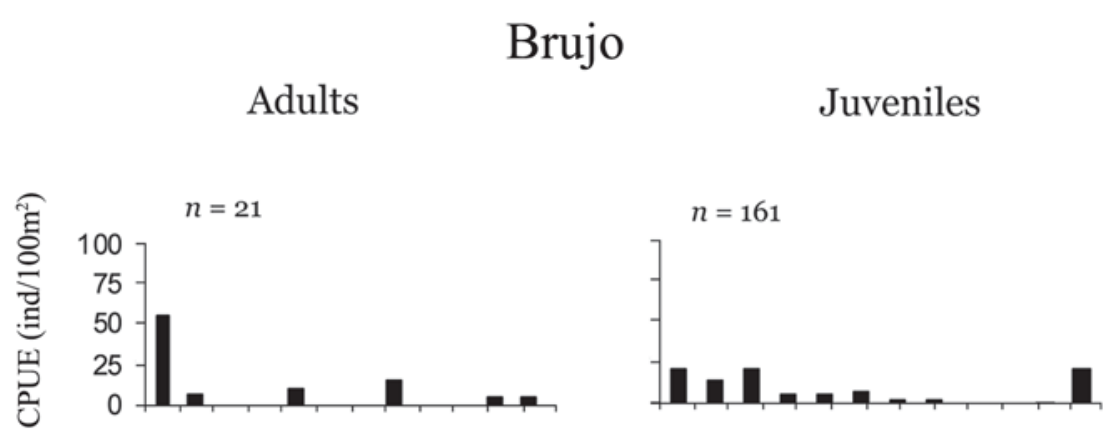

\section{Caña Blancal}
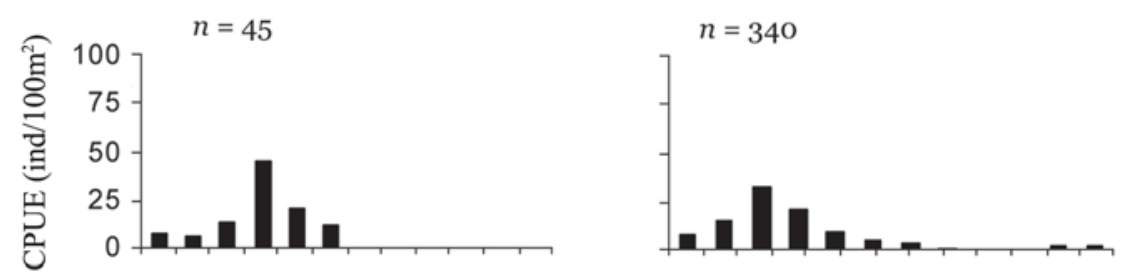

\section{Ojochal}
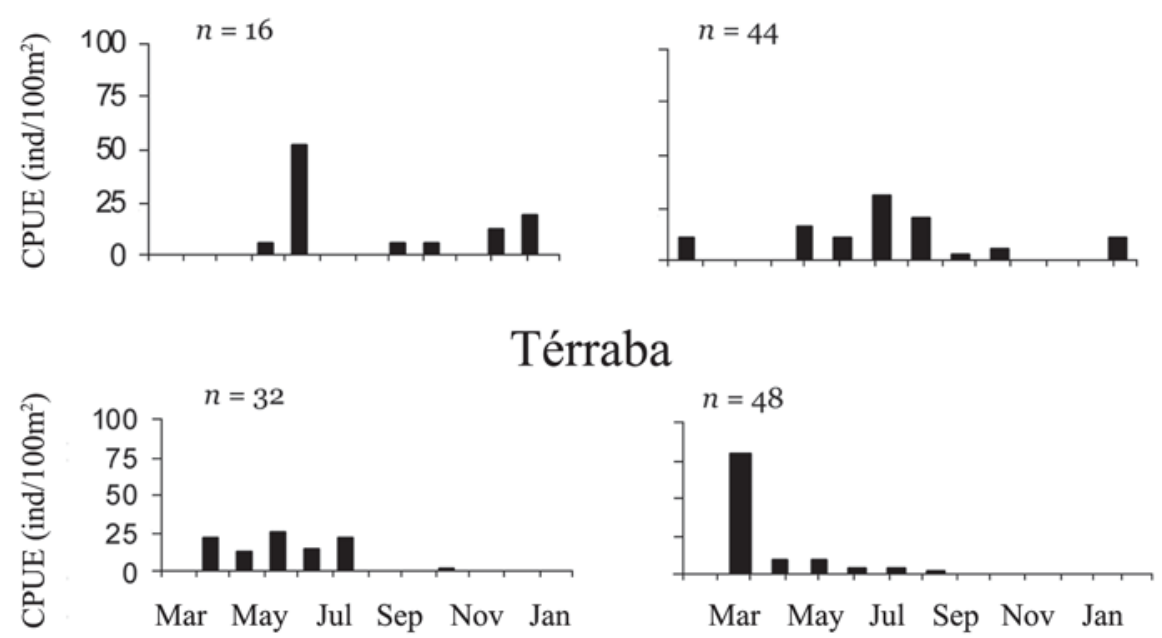

Fig. 6. Capture per unit effort (CPUE) by month for Brycon behreae juveniles and adults in the Térraba River and three tributaries.

maintenance of these species in the ecosystem. Both species presented a similar pattern in all streams, with a higher amount of juveniles. These places may work as shelters, probably because the main river presents a greater amount of predators (personal observation) than the streams (Power, 1987). The highest number of adults of $B$. behreae in Térraba River also corroborates the higher predation risk hypothesis of fish (Krause et al., 1998). Also, small individuals can come to live in shallow places where big fishes usually are not able to reach (Harvey, 1991). In fact, Schlosser (1987) showed that there is a higher density of juvenile individuals and adults of smaller species in shallow regions of the river.

According to the results, we believe that juvenile individuals of these two species use the streams as nursing habitats during their development into adults. On this line of thought these relatively small tributaries were considered by us as essential fish habitats (Lindeman et al., 2000; Bexiga, 2002).

The decrease in abundance of these two species in the streams during the seasons of higher flow and turbidity may be related with the fact that these tributaries are more sensible to changes in flow, presenting relatively greater fluctuations, as observed during this study (Fig. 2). That may even explain the higher turbidity in the streams in October (Fig. 7). The increase in flow carries a greater load of solids in suspension and this can be fatal for fish. For instance the width of Caña Blancal increased from 7 - $9 \mathrm{~m}$ up to $113 \mathrm{~m}$ during the rainy season, when even big rocks were dragged. 
During the season of highest flow, B. behreae comes out of the open regions of Térraba River and concentrates in pools located at its shore and in the streams, where they were observed. It is probably a behaviour related to reproduction judging by the arrival date of recruits in the beginning of the period of low flow. Other studies indicate that this species performs migrations to the headwaters and other regions of moderate to low flow during its reproductive period (Bussing, 2002).

Brycon behreae seem to be less affected to changes in turbidity and flow than A. monticola. Brycon behreae remained in the pools of the streams during the season when both variables reached their highest values. A possible explanation for the presence of $B$. behreae in the streams at the highest turbidity period of the year can be linked to their behaviour. By remaining in the pools where the sedimentation of thicker solids is higher, they experience slightly clearer water. By doing this, this Characid may not really suffer the impact of variations in turbidity sufficient to affect its vital functions.

Meanwhile, the specie $A$. monticola, which normally does not stay in the pools, increased their abundance in Térraba River when it presented a slightly minor turbidity compared to the streams (Fig. 7). This avoidance behavior to high turbidity environments practiced by $A$. monticola has already been mentioned (Cruz, 1987).

The phenomenon of annual recruitment during periods of low flow presented by Brycon behreae (Fig. 3) is also performed by many other Characids, e.g. Astyanax fascicatus of Ceará Mirim River in the North of Brazil (Gurgel, 2004). Maybe this is a more favourable period in the streams to breed.

The species $A$. monticola, according to a study in Honduras, presented a reproductive annual peak related with the rainy seasons (Cruz, 1987). In the Térraba basin, very young individuals (recruits) are present in the streams all year long, presenting a massive peak in Térraba River in the months of July and August (Fig. 4), two months before the increase of flow. The existence of an annual reproductive peak was already

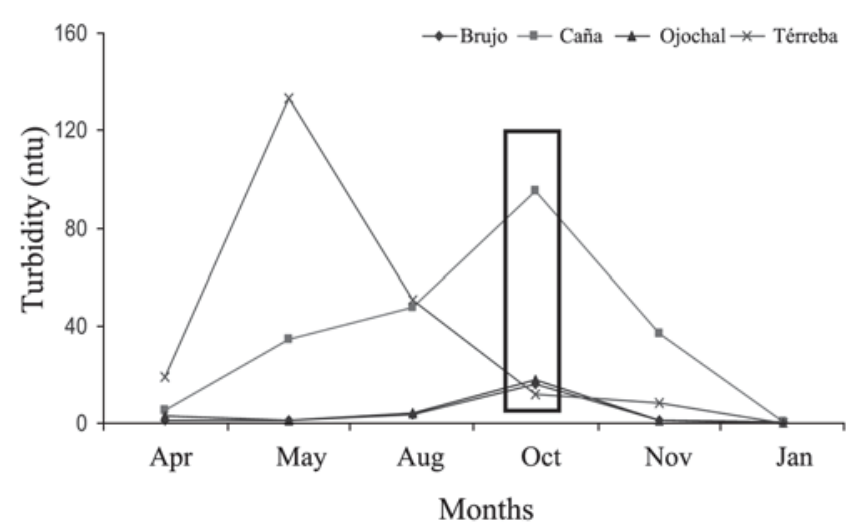

Fig. 7. Turbidity at the main River Térraba and the streams. The marked area is about October, when Térraba was less turbid than streams. described in other studies (Cruz, 1987; Phillip, 1993; Airen, 1998), although in different periods of the year.

Dams are a real obstacle for migration and an extremely disruptive problem (Melvin \& Warren, 1998; Ovidio \& Phillippart, 2002) that can easily compromise the local survival of the species (Prignon et al., 1999; Mathers et al., 2002). Therefore, in order to avoid this ecological disturbance, fish passages were been built at several dams. These passages must allow the continuity of the migratory process (up- and downstream), because the survival of the species needs the arrival of the young fishes at their feeding and growth nursery sites of the hydrographical basin. The massive recruitment of Térraba by non resident $A$. monticola, is probably related to the use of this river as a way to reach the streams (supported by its catadromous condition) (Cruz, 1987; Bussing, 2002), and indicates that it is reasonable to include an efficient fish passage in the designs of the project (Aarestrup et al., 2003; Oldani et al., 2007). However, to implement such structure a study of swimming performance of recruits is needed (Santos et al., 2007) because they may be too small to transpose the fish passage and they probably will need a ladder specially designed for them. The placement of the dam allows the free flow of Coto-Brus River, one of the main branches of Térraba River. Nevertheless, the dam site still affects a large portion of the whole drainage basin, and it is necessary to evaluate the effect of interrupting the migration into the affected river branch, and the need for installing some remedy structures such as fish ladders. These recommendations have the goal to avoid repeating what happened in the Tepemechín River, in Pejibaye (Turrialba), where this species was not found during the field trip made upstream the dam. The presence of $B$. behreae, a neotropical migratory fish restricted to freshwater imparts the need of even more ecological studies and that the implementation of fish passages requires special technical considerations. There are cases where these structures act as fish ecological traps (Pelicice \& Agostinho, 2008) providing only a one way upstream route for migratory fishes (Agostinho et al., 2007). A better approach about the need and effects of the fish passage requires answering the following questions: Is there a reproductive site upstream and downstream of the dam? Are the downstream movements through the dam possible? What is the purpose of keeping these fish upstream of the dam? Is it for conservation of the fishes or just to maintain fisheries? Are there others migratory fishes in that river?

Therefore, some specific studies should still be performed to address the fish passage necessity and effects to the ichthyofauna community at Térraba basin.

Furthermore, the variation in water flow and its influence on the behaviour and population dynamics of these two species, specially regarding the recruitment phenomenon at low flow waters by $B$. behreae before the rainy season, implies that in the case of damming of Térraba River, it is important to allow these variations in water levels to occur along the whole basin, in order to protect the life history of these species. 


\section{Acknowledgements}

We thank to Instituto Costarricense de Energía (ICE) and Centro de Investigaciones Marinas y Limnológicas (CIMAR) for financial and logistic support. We also thank to Luis Salazar, Augusto Gonzalez, Rollier Lara, Omar Rodriguez and Jorge Picado for their help in the field with data collection.

\section{Literature Cited}

Aarestrup, K., M. C. Lucas \& J. A. Hansen. 2003. Efficiency of nature-like bypass channel for sea trout (Salmo trutta) ascending a small Danish stream studied by PIT telemetry. Ecology of freshwater fish, 12: 160-168.

Agostinho, A. A., E. E. Marques, C. S. Agostinho, D. A. Almeida, R. J. Oliveira \& J. R. B. Melo. 2007. Fish ladder of Lajeado dam: migrations on one-way rotes? Neotropical Ichthyology. 5(2): 121-130.

Airen, K. A. 1998. Reproduction, diet and population structure of the mountain mullet, Agonostomus monticola, in Jamaica, West Indies. Environmental Biology, 53(3): 347-352.

Baumar, J., E. Marin, A. Quintero, D. Bussière \& J. Dodson. 2003. Reproduction and recruitment of white mullet (Mugil curema) to a tropical lagoon (Margarita Island, Venezuela) as revealed by otolith microstructure. Fish Bulletin, 101: 809821.

Behr, E. R. \& C. A. Signor. 2008. Distribuição e alimentação de duas espécies simpátricas de piranhas Serrasalmus maculatus e Pygocentrus nattereri (Characidae, Serrasalminae) do rio Ibicuí, Rio Grande do Sul, Brasil. Iheringia, Série Zoologia, 98(4): 501-507.

Bexiga, C., L. Vieira, R. Sá, P. Veiga \& K. Erzini. 2002. Ecological Associations of the Fish Species of the Guadiana River: Habitat Linkages. Pp. 235-237. In: Eurocoast, Sixth International Conference. Littoral: The Changing Coast, 22 - 26 September 2002.

Bergenius, M. A. J., M. I. McCormick, M. G. Meekan \& D. R. Robertson. 2005. Environmental influences on larval duration, growth and magnitude of settlement of a coral reef fish. Marine Biology, 147: 291-300.

Bussing, W. A. 2002. Peces de las aguas continentales de Costa Rica. San José, Costa Rica. Universidad de Costa Rica, 468p.

Colwell, R. K. \& D. J. Futuyma. 1971. On the measurement of niche breadth and overlap. Ecology, 52: 558-567.

Cruz, G. A. 1987. Reproductive biology and feeding habits of coyamel, Joturus pichardi and Tepemechín Agonostomus monticola (Pisces: Mugilidae) from Río Plátano, Mosquita, Honduras. Bulletin of Marine Sciences, 40: 63-72.

Duncan, J. R. \& J. L. Lockwood. 2001. Extinction in a field of bullets: a search for causes in the decline of the world's freshwater fishes. Biological Conservation, 102: 97-105.

Fievet, E., S. Dolédec \& P. Lim. 2001. Distribution of migratory fishes and shrimps along multivariate gradients in tropical island streams. Journal of Fish Biology, 59: 390-402.

Floeter, S. R., R. Z. P. Guimarães, L. A. Rocha, C. E. L. Ferreira, C. A. Rangel \& J. L. Gasparini. 2001. Geographic variation in reef-fish assemblages along the brazilian coast. Global Ecology \& Biogeography, 10: 423-431.
Godinho, F. N., M. T. Ferreira \& R. V. Cortes. 1997. Composition and spatial organization of fish assemblages in the lower Guadiana basin, southern Iberia. Ecology of Freshwater Fish, 6: 134-143.

Guisan, A. \& N. E. Zimmermann. 2000. Predictive habitat distribution models in ecology. Ecological Model ling, 135: 147-186.

Gurgel, H. C. B. 2004. Estrutura populacional e época de reprodução de Astyanax fascicatus (Cuvier) (Characidae, Tetragonopterinae) do Rio Ceará Mirim, Poço Branco, Rio Grande do Norte, Brasil. Revista Brasileira de Biologia, 21(1): 131-135.

Harvey, B. C. 1991. Interactions among stream fishes: predatorinduced habitat shifts and larval survival. Oecologia, 87: 29-39.

Inoue, M. \& M. Nunokawa. 2002. Effects of longitudinal variations in stream habitat structure on fish abundance: an analysis based on subunit-scale habitat classification. Freshwater Biology, 47: 1594-1607.

Krause, J., S. P. Loader, J. McDermott \& G. D. Ruxton. 1998. Refuge use by fish as a function of body length-related metabolic expenditure and predation risks. Proceeds Royal Society of London, 265: 2373-2379.

Leopold, L. B., M. G. Wolman \& J. P. Miller. 1964. Fluvial processes in geomorphology. Dover, New York, 522p.

Lindeman, K. C., R. Pugliese, G. T. Waugh \& J. S. Ault. 2000. Developmental patterns within multispecies reef fishery: management application for essential fish habitats and protected areas. Bulletin of Marine Science, 66(3): 929-956.

Lowe-McConnell, R. H. 1987. Ecological studies in tropical fish communities. Cambridge University Press, 382p.

McDowall, R. M. 1998. Fighting the flow: downstream-upstream linkages in the ecology of diadromous fish faunas in west coast, New Zealand Rivers. Freshwater Biology, 40: 111-122.

Magalhães, M. F. 1993. Feeding of an Iberian stream cyprinid assemblage: seasonality of resource use in a highly variable environment. Oecologia, 96: 253-260.

Magalhães, M. F., D. C. Batalha \& M. J. Pereira. 2002. Gradients in stream fish assemblages across a mediterranean landscape: contributions of environmental factors and spatial structure. Freshwater Biology, 47: 1015-1031.

Mathers, R. G., M. De Carlos, K. Crowley \& D. O'Teangana. 2002. A review of the potential effect of Irish hydroelectric installations on Atlantic salmon (Salmo salar) populations, with particular reference to the River Erne. Biology and Environment, 102(2): 69-79.

Melvin, L. \& J. R. Warren. 1998. Road crossings as barriers to small-stream fish movement. American Fisheries Society, 127: 637-644.

Oldani, N. O., C. R. M. Baigún, J. M. Nestler \& R. A. Goodwin. 2007. Is fish passage technology saving fish resources in the lower La Plata River basin? Neotropical Ichthyology. 5(2): 89-102.

Ovidio, M. \& J. C. Phillippart. 2002. The impact of small physical obstacles on upstream movements of six species of fish. Hydrobiologia, 483: 55-69.

Pelicice, F. M. \& A. A. Agostinho. 2008. Fish-Passage facilities as ecological traps in large Neotropical Rivers. Conservation Biology, 22(1): 180-188.

Phillip, D. A. T. 1993. Reproduction and feeding of the mountain mullet, Agonostomus monticola, in Trinidad, West Indies. Environmental Biology of Fishes, 37: 47-55. 
Power, M. E. 1987. Predator avoidance by grazing fishes in temperate and tropical streams: importance of stream depth and prey size. Pp. 333-351. In: Kerfoot, W. C. \& A. Sih (Eds.). Predation: direct and indirect impacts on aquatic communities. University Press of New England, Hanover, New Hampshire.

Prignon, C., J. C. Micha, G. Rimbaud \& J. C. Phillippart. 1999. Rehabilitation efforts for atlantic salmon in the Meuse basin area: Synthesis 1983-1998. Hydrobiologia, 410: 69-77.

Ribeiro, T. C. \& H. M. Ureña. 2009. Ontogenic changes in the feeding habits of the fishes Agonostomus monticola (Mugilidae) and Brycon behreae (Characidae), Térraba River, Costa Rica. Int. J. Trop. Biol. 57(1): 285-290.

Robertson, M. S. \& K. O. Winemiller. 2003. Habitat associations of fishes in the Devils River. Texas Journal of Freshwater Ecology, 18(1): 116-127.

Santos, H. A., P. S. Pompeu \& C. B. Martinez. 2007. Swimming performance of the migratory Neotropical fish Leporinus reinhardti (Characiformes: Anostomidae). Neotropical Ichthyology, 5(2): 139-146.

Schlosser, I. J. 1987. The hole of Predation in age- and size- related habitat use by stream fishes. Ecology, 68(3): 651-659.

Wanat, J. M. 2002. Using habitat suitability models to identify essential fish habitat for the winter flounder, Pseudopleuronectes americanus, in great bay estuary, N. H. Unpublished M.Sc. Dissertation. University of New Hampshire, 142p.

Accepted August 31, 2010

Published December 16, 2010 